\title{
Bridging mapping and simulation modelling in the ecosystem service assessments of boreal forests: effects of bioenergy production on carbon dynamics
}

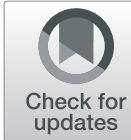

\author{
Anu Akujärvi ${ }^{1,2^{*}}$ D, Anna Repo ${ }^{3}$, Altti M. Akujärvi ${ }^{4}$ and Jari Liski ${ }^{5}$
}

\begin{abstract}
Background: Increasing the use of forest harvest residues for bioenergy production reduces greenhouse emissions from the use of fossil fuels. However, it may also reduce carbon stocks and habitats for deadwood dependent species. Consequently, simple tools for assessing the trade-offs of alternative management practices on forest dynamics and their services to people are needed. The objectives of this study were to combine mapping and simulation modelling to investigate the effects of forest management on ecosystem services related to carbon cycle in the case of bioenergy production; and to evaluate the suitability of this approach for assessing ecosystem services at the landscape level. Stand level simulations of forest growth and carbon budget were combined with extensive multi-source forest inventory data across a southern boreal landscape in Finland. Stochastic changes in the stand age class distribution over the study region were simulated to mimic variation in management regimes.

Results: The mapping framework produced reasonable estimates of the effects of forest management on a set of key ecosystem service indicators: the annual carbon stocks and fluxes of forest biomass and soil, timber and energy-wood production and the coarse woody litter production over a simulation period 2012-2100. Regular harvesting, affecting the stand age class distribution, was a key driver of the carbon stock changes at a landscape level. Extracting forest harvest residues in the final felling caused carbon loss from litter and soil, particularly with combined aboveground residue and stump harvesting. It also reduced the annual coarse woody litter production, demonstrating negative impacts on deadwood abundance and, consequently, forest biodiversity.
\end{abstract}

Conclusions: The refined mapping framework was suitable for assessing ecosystem services at the landscape level. The procedure contributes to bridging the gap between ecosystem service mapping and detailed simulation modelling in boreal forests. It allows for visualizing ecosystem services as fine resolution maps to support sustainable land use planning. In the future, more detailed models and a wider variety of ecosystem service indicators could be added to develop the method.

Keywords: Carbon budget, Ecosystem services, Forest management, Forest bioenergy, Landscape level, Mapping, Modelling

\footnotetext{
* Correspondence: anu.akujarvi@syke.fi

${ }^{1}$ Finnish Environment Institute SYKE, Biodiversity Centre, Latokartanonkaari

11, Fl-00790 Helsinki, Finland

${ }^{2}$ University of Helsinki, Department of Geosciences and Geography, P.O. Box

64, Fl-00014 Helsinki, Finland

Full list of author information is available at the end of the article
}

\section{Springer Open}

(c) The Author(s). 2021 Open Access This article is licensed under a Creative Commons Attribution 4.0 International License which permits use, sharing, adaptation, distribution and reproduction in any medium or format, as long as you give appropriate credit to the original author(s) and the source, provide a link to the Creative Commons licence, and indicate if changes were made. The images or other third party material in this article are included in the article's Creative Commons licence, unless indicated otherwise in a credit line to the material. If material is not included in the article's Creative Commons licence and your intended use is not permitted by statutory regulation or exceeds the permitted use, you will need to obtain permission directly from the copyright holder. To view a copy of this licence, visit http://creativecommons.org/licenses/by/4.0/. 


\section{Background}

Bioenergy, produced from harvest residues such as branches, tree tops and stumps, is an increasing form of utilising boreal and northern temperate forests (DiazYanez et al. 2013; Scarlat et al. 2015). Bioenergy reduces fossil carbon emissions to the atmosphere. However, increased biomass harvesting reduces the carbon stocks of forest which may partly reduce the climate benefits of forest bioenergy (Schlamadinger et al. 1995; Repo et al. 2011; Schulze et al. 2012; Zanchi et al. 2012; Mäkipää et al. 2014). In addition, the increased biomass extraction in the boreal regions has also raised concerns about the degradation and loss of habitats of deadwood dependent species (Bouget et al. 2012). The volume of deadwood is strongly correlated with the richness of threatened species: birds (Virkkala 2016), insects (Martikainen et al. 1999), and fungi (Penttilä et al. 2006), which makes it a good biodiversity indicator.

The climate impacts of forest bioenergy have been studied extensively in recent years using simulation models (Wihersaari 2005; Eriksson et al. 2007; Melin et al. 2010; Kilpeläinen et al. 2011; Repo et al. 2011, 2012). One approach has been to scale up stand level estimates of the $\mathrm{CO}_{2}$ emissions resulting from carbon stock changes to the national level by assuming a uniform age class distribution of the forest stands (Cherubini et al. 2013). This approach approximates the total $\mathrm{CO}_{2}$ emissions from a regularly managed forested landscape. The age class distribution has, however, a significant effect on the net emission estimates from energy wood use (Routa et al. 2012). Ignoring the high variability of forest structure and the irregular occurrence of harvests might add inaccuracy to the landscape level estimates of carbon budget. The spatial resolution of the carbon stock changes could be improved by coupling remote sensing- and inventory-based observations of forest characteristics with simulation modelling (Paulick et al. 2017). This kind of approach could be applied to illustrate the climate effects of alternative bioenergy production scenarios across an actual landscape where decisions are made. Mapping can reveal the most suitable areas for bioenergy production in terms of resource availability (Verkerk et al. 2019). It could also be applied to identify spatial trade-offs and synergies between bioenergy production and other ecosystem service indicators, such as carbon sequestration and deadwood production (Sacchelli et al. 2013).

The present status and past changes of ecosystem services can be mapped using remote sensing (Vauhkonen 2018; Li et al. 2019) or readily available land cover and land use data (Lautenbach et al. 2011; Mononen et al. 2017). The provisioning potential of ecosystem services is often quantified using simple land cover -based proxies if direct mapping is not possible (Smith et al. 2006; Nelson et al. 2009; Burkhard et al. 2012; Maes et al. 2012). However, the use of land cover -based proxies may simplify the spatiotemporal variability of climate regulation by assuming, for instance, constant carbon stocks per land cover class. This makes the maps prone to errors (Eigenbrod et al. 2010). Empirical and process-based modelling includes more detailed description of forest growth based on measurements or ecological theory. Simulation modelling, in combination with remote sensing data, has been applied to map regulating and provisioning ecosystem services at various spatial scales (e.g. Sitch et al. 2003; Schröter et al. 2005; Mina et al. 2017; Holmberg et al. 2019; Verkerk et al. 2019). However, the complex structure and data requirements of models might limit their use in ecosystem service assessments at a fine spatial resolution due to the lack of suitable remote sensing data (Lavorel et al. 2017). This indicates a disparity between the scientific knowledge about carbon dynamics and its implementation to mapping tools. Consequently, simple dynamic tools are needed to evaluate the effects of alternative forest management practices on ecosystem services at varying spatial scales (Crossman et al. 2013).

To contribute to bridging the gap between proxybased mapping and detailed simulation modelling in studies investigating the future provisioning of ecosystem services, a framework for quantifying the carbon budget of boreal forested landscapes was developed (Akujärvi et al. 2016). It coupled simulated timeseries of carbon stocks with extensive, publicly available forest inventory data (Tomppo et al. 2014). This relatively simple method enabled reliable mapping of the current status of carbon budget at the landscape level, complementing previous approaches. However, the suitability of this framework for investigating the effects of alternative forest management scenarios on the availability of ecosystem services in the future remains to be tested.

The first objective of this study was to apply the previously developed framework for simulating the future development of ecosystem services related to carbon cycle, particularly in the case of bioenergy production. The second objective was to evaluate the suitability of this approach for assessing ecosystem services at the landscape level. The studied ecosystem service indicators were the carbon stocks and fluxes of forest biomass and soil, timber and energy-wood production and the annual coarse woody litter production, used as a proxy for deadwood abundance. They were simulated for a boreal forested catchment in southern Finland for the period 2012-2100. The validity of the mapping framework was evaluated by comparing the simulated estimates with measurement-based data. 


\section{Methods}

\section{Study area}

The study area Vanajavesi catchment in the southern boreal forest zone belongs to the Kokemäenjoki river basin in southern Finland (Fig. 1). It consists of 10 subcatchments of the second level of the Finnish watershed division. Most of the catchment is within the region of Kanta-Häme. The annual mean temperature was $4.2{ }^{\circ} \mathrm{C}$ and the annual precipitation $637 \mathrm{~mm}$ during 1970-2012. The total area of the catchment is $2700 \mathrm{~km}^{2}$, of which $1425 \mathrm{~km}^{2}$ is managed forest covered by the model simulations of this study. The proportion of peatlands in Kanta-Häme is $17 \%$, of which nearly all are forested and about three quarters drained (Natural Resources Institute Finland 2020). Despite the relatively high proportion of peatland forests in the study area they were excluded from the simulations. This was because the litter and soil carbon model Yasso operates only on mineral soils. The Natura 2000 protected habitats (Evans 2012) and nature conservation and wilderness areas, protected by the Nature Conservation Act, cover altogether $3 \%$ of the catchment area. The protected forests were considered to affect the total carbon budget of the study area little due to their small cover. They were thus excluded from the analyses. Fertile site types, usually dominated by spruce and deciduous trees, covered as much as $90 \%$ of the forest area on the mineral soils in
Häme-Uusimaa in 2009-2013. The average cover of these site types is about $75 \%$ in Southern Finland. Planting or natural regeneration, regular thinning and clearcutting are common forest management practices in the study area. In 2012, about $16 \%$ of the harvest removal consisted of energy-wood, of which 30\% was spruce (Natural Resources Institute Finland 2020).

\section{Mapping framework}

A previously developed framework (Akujärvi et al. 2016) was refined to simulate key ecosystem service indicators related to the carbon cycle of forests: carbon stocks and fluxes of biomass, litter and soil, timber and energywood production, and coarse woody litter production. The development of these variables was simulated over the study area for 2012-2100 with standard forest management practices combined with varying levels of harvest residue extraction for bioenergy production. The variability of actual management interventions was considered by stochastic simulations of the stand age class distribution over the simulation period. This could improve the ecosystem service estimates in comparison with some previous studies applying fixed age class distributions (Routa et al. 2012; Frank et al. 2015; Pang et al. 2017).

The mapping framework coupled extensive multisource forest inventory data with simulation modelling

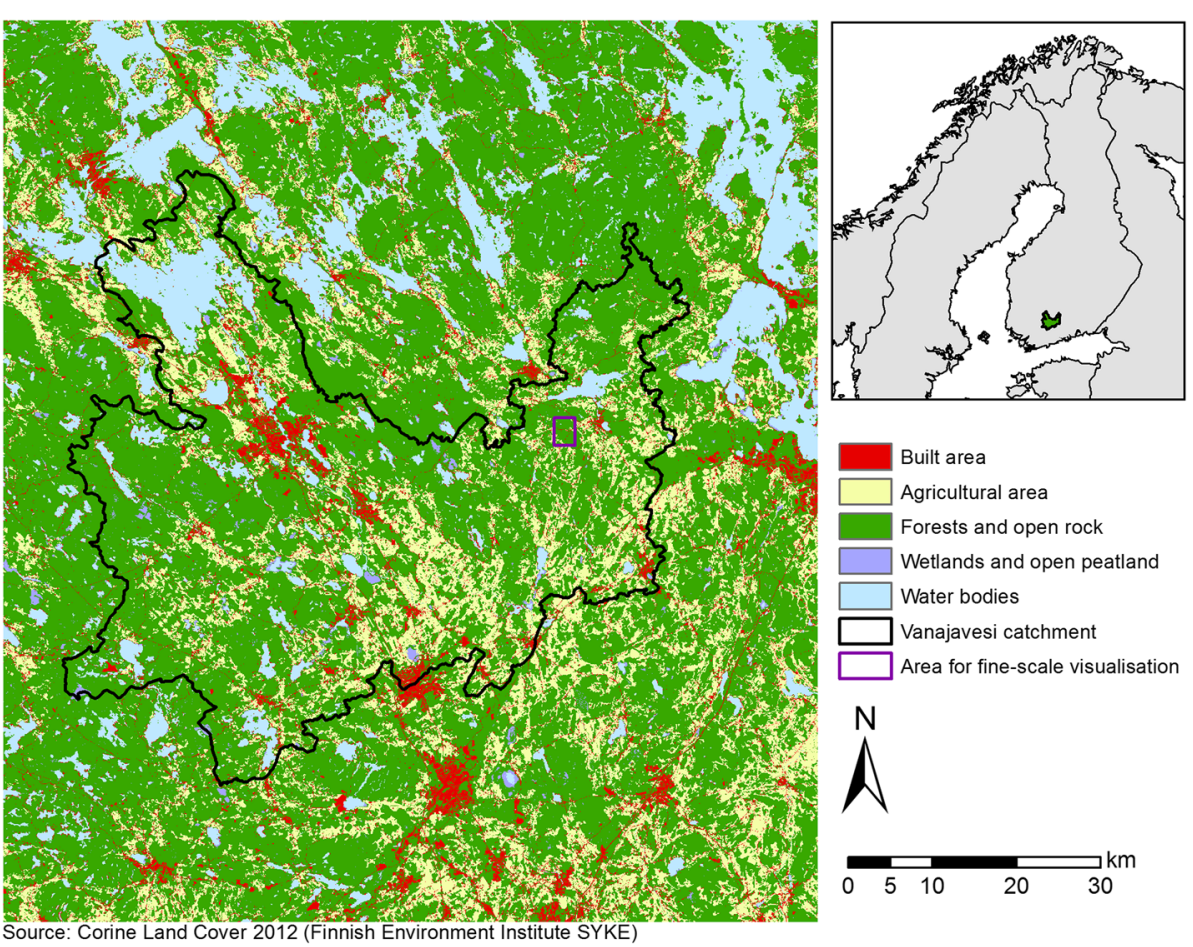

Fig. 1 Land use in the southern boreal Vanajavesi catchment area in Finland in 2012. The location for the fine-scale visualisation of the results is marked with a purple line. CORINE land cover data was provided by Finnish Environment Institute 
of forest carbon dynamics at the stand level. The carbon stock of biomass, timber and energy-wood production and the production of coarse woody litter were simulated using the MOTTI v. 3.3 stand simulator (Hynynen et al. 2002; Salminen et al. 2005). Coarse woody litter production was used as proxy for deadwood abundance and for this purpose it was defined to consist of tree tops and stumps, not including coarse roots. It was coupled with the litter and soil carbon model Yasso15 to estimate the belowground carbon stocks and the changes in them (Tuomi et al. 2009, 2011a, 2011b; Repo et al. 2016). The model simulations were carried out separately for altogether 18 forest site type and main tree species combinations present in the study area (Table 1) and generalised for the entire study area using look-up tables and multi-source forest inventory data.

The performance of the mapping framework has been evaluated previously at a fine spatial resolution in southern Finland by Akujärvi et al. (2016). According to their results, the method produced reliable estimates of the current status of forest carbon stocks and changes. The previous validity test is a sound basis for applying the framework for scenario analysis in the present study because the model simulations and initial land cover data were identical. However, the reliability of the simulated ecosystem service indicators was also evaluated broadly in this study. The simulated mean estimates for the study area in the beginning of the simulation period in 2012 were compared with inventory-based estimates taken previously from the same area.

\section{Forest management scenarios}

In the simulations, forests were assumed to be managed according to the Finnish good practice guidance for forestry with adaptations related to the rotation length. The stand regeneration method, and the timing and intensity of thinning followed the guidelines (Sved and Koistinen 2015). After planting or natural regeneration, the stands were thinned two to three times depending on the mean rotation length, which varied between 65 and 120 years (Table 1). The mean rotation lengths were determined based on the inventory-based range of mean stand age in the study area. They were similar to the upper range

Table 1 The mean rotation length assumed for the site type and tree species -combinations present in the study area. The site types were classified according to Cajander (1949)

\begin{tabular}{lllllll}
\hline Main tree species & \multicolumn{2}{l}{ Site type } \\
\cline { 2 - 7 } & OMaT & OMT & MT & VT & CT & CIT \\
\hline Scots pine (Pinus sylvestris) & 90 & 90 & 110 & 110 & 90 & 120 \\
Norway spruce (Picea abies) & 90 & 90 & 110 & 110 & 120 & 90 \\
Silver birch (Betula pendula) & 90 & 70 & 90 & 65 & 100 & 70 \\
\hline
\end{tabular}

OMaT Oxalis-Maianthemum, OMT Oxalis-Myrtillus, MT Myrtillus, VT Vaccinium, CT Calluna and CIT Cladina Type of the recommended rotation lengths (Sved and Koistinen 2015). Consequently, final felling was conducted only on mature stands. To account for the deviations of practical forest management from the recommended rotation lengths, stochastic variation of the regeneration age was introduced.

The effects of forest bioenergy production on the carbon budget were assessed by comparing the extraction of forest harvest residues to a scenario under which they were left on site to decompose. Harvest residues were extracted only from the fertile Norway spruce sites (OMaT, OMT, MT and VT site classes, see Table 1), mimicking the national good practice guidelines for energy-wood harvesting in Finland (Koistinen et al. 2016). Three scenarios were studied. In the reference scenario 1, all forest harvest residues were left on site to decompose and no bioenergy was produced. In scenario $2,70 \%$ of the aboveground harvest residues (branches and tree tops) were extracted for bioenergy production from the final felling sites. In scenario $3,70 \%$ of the aboveground residues, stumps and roots were extracted.

\section{Forest stand simulations}

The carbon stock of biomass was estimated over the rotation period using the MOTTI v.3.3 stand simulator (Salminen et al. 2005; Hynynen et al. 2014). It is based on empirical growth and yield models describing the structure, growth and management of the most typical site types and tree species in Finland (Hynynen et al. 2002). They have been compiled and validated based on extensive forest inventories and field experiments (Matala et al. 2003). Because the MOTTI v. 3.3 simulator uses a time-step of five years, the intermediate annual values were produced by linear interpolation. The annual estimates of timber, energy-wood and coarse woody litter production were produced by converting the dry biomass estimates to fresh volume using a conversion coefficient of $400 \mathrm{~kg} \cdot \mathrm{m}^{-3}$, which is a mean for pine, spruce and birch (Alakangas et al. 2016). Coarse woody litter production was assumed to consist of tree tops and stumps, which represented the large-diameter fractions of deadwood forming litter. In Finland, the diameter of tree tops used for bioenergy production is 4-6 cm (Karttunen et al. 2016). In the output of the MOTTI simulations, the basal-area weighed mean diameter of the mature stands varied between 21 and $47 \mathrm{~cm}$, depending on site type. The diameters of different biomass compartments, such as stumps, were not reported explicitly in the model output. In managed forests, a significant proportion of the deadwood is formed during thinning and final felling from forest harvest residues (Eräjää et al. 2010). In this study, the annual production of coarse woody litter was assumed to indicate the potential deadwood biomass in the future. Deadwood is a 
widely used indicator for forest biodiversity (Gao et al. 2015).

The output of MOTTI v.3.3 was used as input to Yasso15, an improved version of the Yasso litter and soil carbon model (Tuomi et al. 2009, 2011a, 2011b). Yasso15 was used to estimate the soil organic carbon stock, the annual changes in it and the heterotrophic respiration over the rotation period. The carbon input to soil consisted of natural mortality, forest harvest residues and the annual litter production of living trees and ground vegetation. They were estimated with the same method as in the national greenhouse gas inventory of Finland (Ortiz et al. 2013; Sievänen et al. 2014; Statistics Finland 2018). The annual litter production of the living trees was estimated by multiplying the biomass compartments of standing trees, derived from the output of MOTTI v. 3.3, with compartment- and species-specific turnover rates (Liski et al. 2006). The litter production of ground vegetation was equal to the estimates used in the national greenhouse gas inventory (Muukkonen and Mäkipää 2006). The carbon content of biomass was assumed to be $50 \%$.

In the Yasso15 model, soil organic carbon is divided into four chemical compound groups: ethanol soluble (denoted with E), water soluble (W), acid hydrolysable (A), non-soluble $(\mathrm{N})$. The decomposition rate of each compound group depends on temperature and precipitation and results in the formation of more recalcitrant humus $(\mathrm{H})$. The decomposition rate of woody litter depends also on its physical diameter (Tuomi et al. 2011a). The chemical quality of non-woody and woody litter was derived from previous studies (Ortiz et al. 2013; Sievänen et al. 2014). A mean diameter of $2 \mathrm{~cm}$ was assumed for branches and roots, and $15 \mathrm{~cm}$ for stems and stumps. The litter and soil carbon stock was initialised by first running the model to a steady state with average climate and litter production values over one rotation period. The model was then run for a second rotation before the start of the actual simulation period in 2012. Consequently, the litter and soil carbon stock in 2012 demonstrated the situation right after final felling in the bioenergy scenarios 1-3. The average climate in 19702012 (Finnish Meterological Institute 2020) and average litter production over the rotation period were used. The mean annual precipitation, temperature, and temperature amplitude were calculated based on the daily observations from the Lammi weather station located in the study area.

To demonstrate the fine-scale spatial pattern of the carbon fluxes, the net ecosystem production (NEP) of forest was visualised for an $8 \mathrm{~km}^{2}$ sized subset of the study area (Fig. 1) for 2012, 2050, and 2080 which demonstrate well the temporal variation in this variable. The NEP represents the net uptake of carbon of forest before subtracting harvest removals. It is calculated as the difference between net primary production (NPP) and heterotrophic respiration $\left(R_{h}\right)$. NPP consists of the annual change in the carbon stock of biomass, litter production, harvest removals and natural mortality. The net carbon balance of the forest, i.e. the net biome production (NBP), is determined by the revenues by NEP and expenditures by harvests (see for example Liski et al. 2006).

\section{Forest landscape simulation}

The simulated stand-level estimates of ecosystem service indicators were connected to spatially explicit information on forest site type, tree species, biomass and stand age. These data were extracted from the Multisource National Forest Inventory (hereafter MS-NFI) dataset representing year 2011 for the studied catchment. The Finnish MS-NFI produces a wide suit of regularly updated forest variables applicable for ecosystem service assessments from landscape up to national scale (Vauhkonen and Ruotsalainen 2017; Kangas et al. 2019). The MS-NFI forest resource maps are based on extensive NFI field plot measurements, high-resolution satellite images and digital maps, and the non-parametric $k$ Nearest Neighbours estimation (Katila and Tomppo 2001; Tomppo et al. 2008a; Tomppo et al. 2008b). The spatial resolution of the MS-NFI data was $20 \mathrm{~m} \times 20 \mathrm{~m}$.

To set the initial state of the simulated forests in 2011, each grid cell of the stand age layer of the MS-NFI data was classified based on the forest site type and main tree species present in that cell. The main tree species was determined as the species having the maximum biomass among Scots pine (Pinus sylvestris L.), Norway spruce (Picea abies (L.) H. Karst) and deciduous species, comprising mainly of Silver birch (Betula pendula Roth) and Downy birch (Betula pubescens Ehrh.). Only one site type and tree species combination was assigned to each grid cell. The stand age distribution at the initial state, based on the multisource forest inventory, was not altered in the classification procedure (for more details, see Akujärvi et al. 2016).

To project the development of ecosystem service indicators at the landscape level, the stand age layer was updated annually over the simulation period 2012-2100. The site type and main tree species composition were assumed to remain the same as in the initial state. To mimic the variation of the regeneration age in practical forest management, probabilities of final felling were applied for each site type and tree species combination. This approach was chosen because the guidelines are not usually followed strictly in practical forest management. The probabilities were determined by assuming each combination a normally distributed rotation length with a mean following the guidelines (Sved and 
Koistinen 2015) and with a standard deviation of 10 years (Table 1). This deviation was considered reasonable in comparison with typical rotation lengths in southern Finland. For example, the mean rotation length of a spruce stand growing on Oxalis-Myrtillus site type was 90 years, ranging from 80 to 100 years. In other words, the simulated rotation length within this class varied stochastically among grid cells. On every simulation year, the forest in each grid cell was either spared or felled based on the probability of final felling that year. This procedure resulted in a new stand age layer representing each simulation year. The simulation method produced regular harvesting and a steady behaviour of the stand age distribution yet accounting for the stochasticity of actual management interventions (Fig. S1). To map the simulated ecosystem service indicators, they were joined to the annual stand age layers using look-up tables.

\section{Model performance}

To evaluate the performance of the mapping framework, the simulated estimates in the beginning of the study period in 2012-2016 were compared with measurements derived from literature and forest statistics. The litter and soil carbon stock (Rantakari et al. 2012) was measured from permanent sampling plots in southern Finland for the first time in 1985 and again in 2006 (Mäkipää and Heikkinen 2003). The carbon stock of biomass, and its change were calculated based on the mean sample plot estimates of the national forest inventory in the region of Kanta-Häme in 2009-2018. Timber and energy-wood removal were measured from Häme-Uusimaa forestry region in 2009-2014. The simulated results represent a sample of forests located within these regions.

The biomass carbon stock change was estimated based on the measured growth and removal of stems. This approach was chosen because in managed forests, the biomass carbon stock change mainly depends on harvesting, and measurements of stem biomass, growth and removal are readily available from the study area. The growth rate of stem biomass was assumed to be the same as that of stem volume. The biomass carbon stock change was then estimated by subtracting the harvest removal (consisting of timber and energy-wood) from stem growth. The standard deviation of the simulated and measured estimates was calculated between the simulation years and the available measurement periods, respectively. The tree data were derived from the statistical database of the Natural Resources Institute Finland (Natural Resources Institute Finland 2020).

The estimates of annual coarse woody litter production could not be compared with inventory-based estimates of deadwood volume because of methodological differences. The simulated estimate represents the potential input or flow of coarse woody litter to the ecosystem. The inventory-based deadwood volume is a stock. Moreover, only snags and logs over $10 \mathrm{~cm}$ thick and 1.3 $\mathrm{m}$ long are measured. Deadwood, litter and soil organic carbon (SOC) pools are not separated in the output of the Yasso15 model (Tuomi et al. 2011b; Didion et al. 2016). A proper comparison of the simulated and inventory-based estimates of deadwood would require modelling the decay of large-diameter deadwood separately from the decomposition of carbon pools (Herrmann et al. 2015). This could be a subject of further development of this research. To illustrate the role of the initial age class distribution on the regional carbon stock estimates, the simulated and measured age class distribution in the beginning of the simulation period were compared (Fig. S2). The simulated estimate was based on the combination of 1) the multisource NFI data from 2011, which is already generalized data based on the field samples and remote sensing data and 2) the applied forest management scenarios over five first years. The measured estimate is based only on the NFI field plot samples.

\section{Results}

\section{Carbon stocks and fluxes}

The annual mean estimates of carbon stocks and fluxes were presented as means over the studied landscape to illustrate their temporal variation (Figs. 2, 4). The simulated carbon stock of biomass fluctuated between 5.4 and $7.3 \mathrm{~kg} \cdot \mathrm{m}^{-2}$ over the simulation period $2012-2100$, independent of the bioenergy scenario studied (Fig. 2a). In the beginning of the simulation period in 2012, the simulated carbon stock of biomass was about $25 \%$ higher than the measured mean in the surrounding region (Table 2). The carbon stock of biomass decreased at a mean rate of $-0.003 \mathrm{~kg} \cdot \mathrm{m}^{-2} \cdot \mathrm{year}^{-1}$ in $2012-2100$, independent of the bioenergy scenario studied. The rate of biomass carbon stock change varied between -0.07 and $0.07 \mathrm{~kg} \cdot \mathrm{m}^{-2} \cdot$ year $^{-1}$ (Fig. 2b). In 2012, the simulated biomass carbon stock change was almost twice as much as the measurement-based mean (Table 2).

The litter and soil carbon stock remained relatively stable over the simulation period, varying between 8.5 and $8.8 \mathrm{~kg} \cdot \mathrm{m}^{-2}$ (Fig. 2c). The simulated estimates were within the upper end of the range of the measured litter and soil carbon stock estimates (Table 2). Forest bioenergy production caused a mild decrease in the litter and soil carbon stock compared with stem-only harvest. In 2100 , the litter and soil carbon stock was $1 \%$ and $4 \%$ lower in scenarios 2 and 3, respectively, than in the reference scenario 1 . The litter and soil carbon stock increased at a mean rate of $0.007 \mathrm{~kg} \cdot \mathrm{m}^{-2} \cdot \mathrm{year}^{-1}$, with a range of $-0.003-0.017 \mathrm{~kg} \cdot \mathrm{m}^{-2} \cdot \mathrm{year}^{-1}$ (Fig. 2d). The 

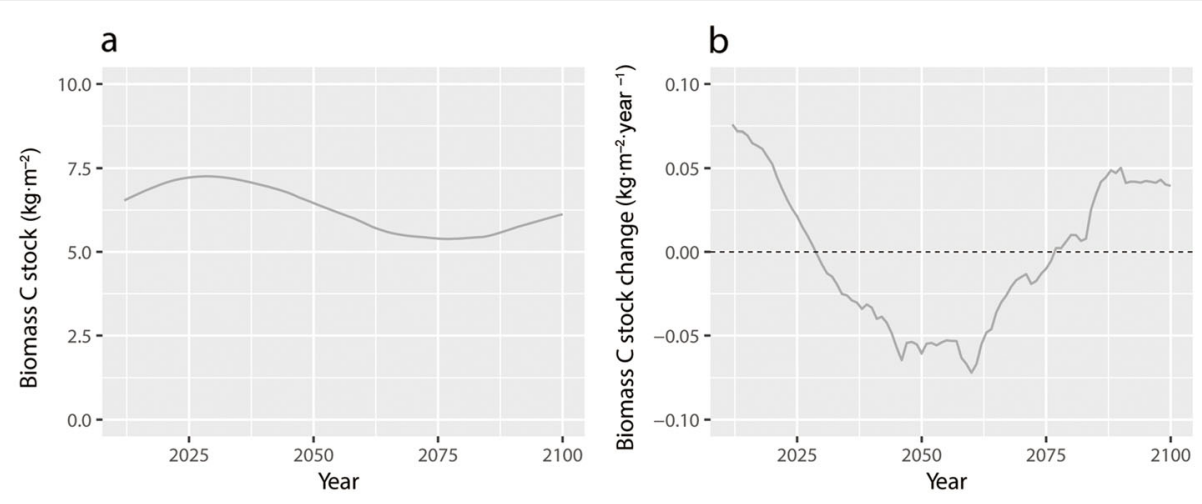

C

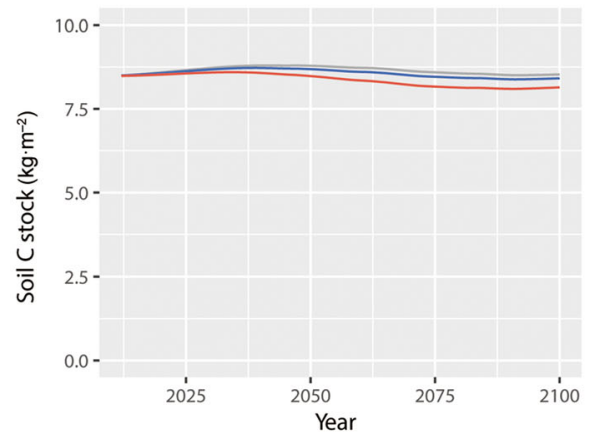

d
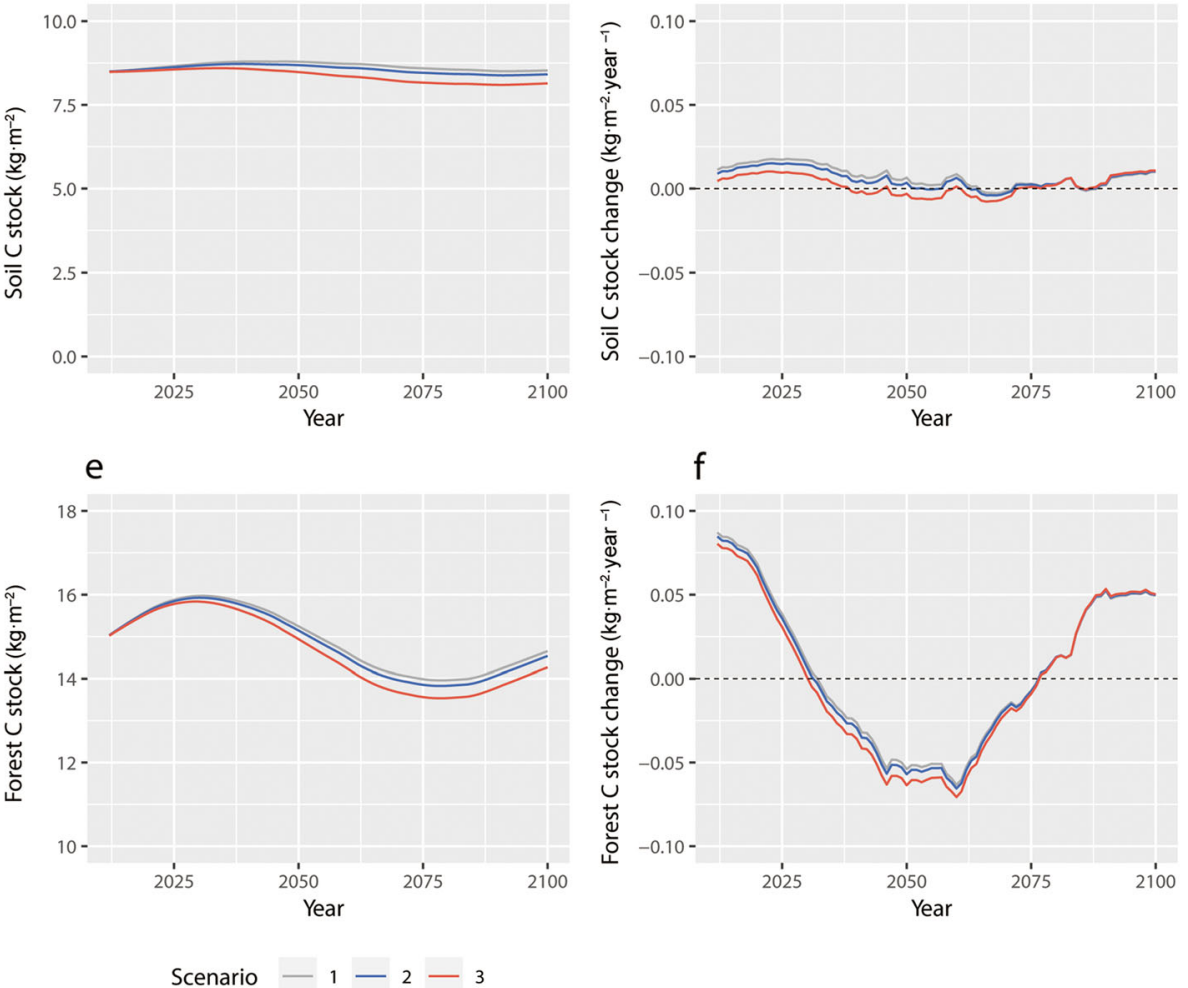

Fig. 2 The mean simulated carbon stocks of biomass, litter and soil and the annual changes in these stocks in the study area over the simulation period 2012-2100. The total carbon stock of forest is the sum of biomass, litter and soil carbon stocks. Positive values of carbon stock change indicate a sink of carbon, and negative values a source. The bioenergy scenarios 1-3 represent varying level of harvest residue removal: 1) no extraction of harvest residues, 2) extraction of branches and tree tops for bioenergy production, 3) extraction of branches, tree tops and stumproot systems for bioenergy production

simulated estimate of the litter and soil carbon stock change was very similar to the measured mean (Table 2).

The more biomass was extracted for bioenergy production, the slower was the accumulation of soil carbon. The soil carbon sink was $18 \%$ and 59\% lower in scenarios 2 and 3, respectively, than in scenario 1 in the beginning of the simulation period in 2012 (Fig. 2d). The differences between the scenarios levelled off towards the end of the simulation period. This was because the residues from the earlier harvests had mostly decomposed and the volume of energy-wood harvests started to decline (Fig. 5b). The changes in the total carbon stock of forest were mainly driven by the changes in the carbon stock of biomass rather than the bioenergy scenarios. The total carbon sink was 3\% and 9\% lower in scenarios 2 and 3, respectively, than in scenario 1 in the beginning of the simulation period in 2012 (Fig. 2f).

Maps of net ecosystem production (NEP) demonstrate the fine-scale spatial variation of carbon fluxes across a 
Table 2 The simulated mean ecosystem service indicators for the study area in 2012-2016 compared with measurements taken from the surrounding regions (SF stands for Southern Finland, KH for Kanta-Häme and HU for Häme-Uusimaa, respectively). The litter and soil carbon estimates from the BioSoil (BS) data were derived from Rantakari et al. (2012) and those of the National Forest Inventory (NFI) from the statistical database of the Natural Resources Institute Finland (2020)

\begin{tabular}{|c|c|c|c|c|c|c|c|}
\hline \multirow[t]{2}{*}{ Variable } & \multicolumn{2}{|l|}{ Simulated } & \multicolumn{5}{|c|}{ Measured } \\
\hline & Mean & SD & Mean & SD & Period & Area & Source \\
\hline Soil carbon stock $\left(\mathrm{kg} \mathrm{C} \cdot \mathrm{m}^{-2}\right)$ & 8.5 & 0.02 & 6.7 & 3 & 2006 & SF & BS \\
\hline Soil carbon change $\left(\mathrm{kg} \mathrm{C} \cdot \mathrm{m}^{-2} \cdot\right.$ year $\left.^{-1}\right)$ & 0.013 & 0.001 & 0.012 & 0.06 & 1985-2006 & SF & BS \\
\hline Biomass carbon stock $\left(\mathrm{kg} \mathrm{C} \cdot \mathrm{m}^{-2}\right)$ & 6.7 & 0.11 & 5.9 & 0.42 & 2009-2018 & $\mathrm{KH}$ & $\mathrm{NFI}$ \\
\hline Biomass carbon stock change $\left(\mathrm{kg} \mathrm{C} \cdot \mathrm{m}^{-2} \cdot\right.$ year $\left.{ }^{-1}\right)$ & 0.071 & 0.004 & 0.041 & 0.005 & 2009-2018 & $\mathrm{KH}$ & $\mathrm{NFI}$ \\
\hline Timber harvest, all tree species $\left(\mathrm{m}^{3} \cdot \mathrm{ha}^{-1} \cdot\right.$ year $\left.{ }^{-1}\right)$ & 5.2 & 0.12 & 4.9 & 0.55 & 2009-2014 & $\mathrm{HU}$ & $\mathrm{NFI}$ \\
\hline Energy-wood harvest, spruce $\left(\mathrm{m}^{3} \cdot \mathrm{ha}^{-1} \cdot \mathrm{year}^{-1}\right)$ & $0.14^{1}, 0.40^{2}$ & $0.01^{1}, 0.03^{2}$ & 0.27 & 0.04 & 2009-2014 & $\mathrm{HU}$ & $\mathrm{NFI}$ \\
\hline
\end{tabular}

${ }^{1}$ Scenario 2 (only branches and tree tops), ${ }^{2}$ Scenario 3 (branches, tree tops and stumps)

subset of the studied landscape (Fig. 3). The mean annual NEP decreased at first as a result of regular harvesting and, consequently, the increasing proportion of regeneration stands. The forest acted as a source of carbon to the atmosphere in the middle decades of the simulation period because the harvest removals exceeded NEP (Fig. 4). The spatial patches of NEP became more fragmented as more grid cells were harvested (Fig. 3).

The spatiotemporal pattern of carbon uptake reflected the changes in stand age class distribution resulting from regular harvesting which was simulated with a stochastic a

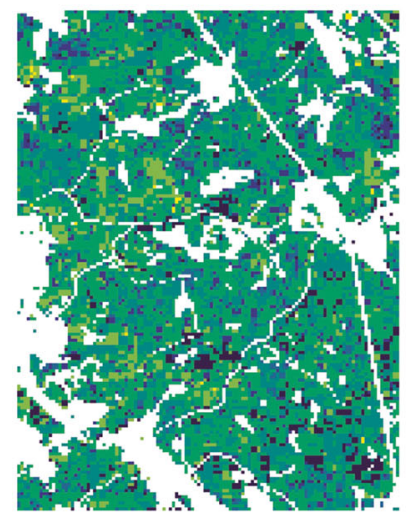

C

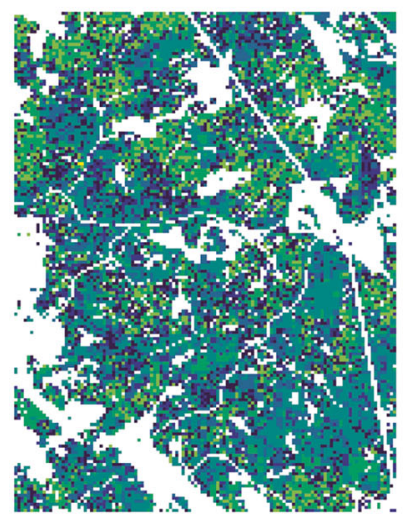

b

\section{NEP in 2012}

$(-0.3,-0.1]$

$(-0.1,0]$

$(0,0.1]$

$(0.1,0.2]$

$(0.2,0.4]$

$(0.4,0.5]$

$(0.5,0.6]$

NA

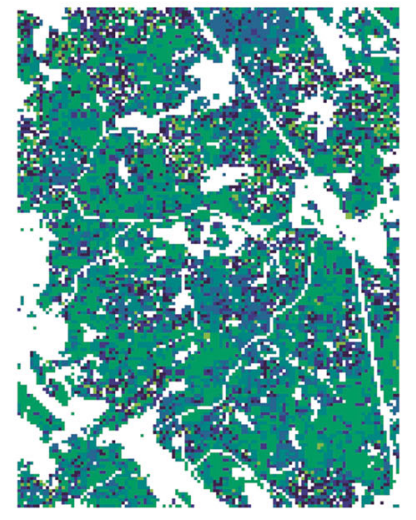

NEP in 2040

$(-0.3,-0.1]$

$(-0.1,0]$

$(0,0.1]$

$(0.1,0.2]$

$(0.2,0.4]$

$(0.4,0.5]$

NA

d

NEP in 2060

$(-0.3,-0.1]$

$(-0.1,0]$

$(0,0.1]$

$(0.1,0.2]$

$(0.2,0.4]$

$(0.4,0.5]$

$(0.5,0.6]$

NA

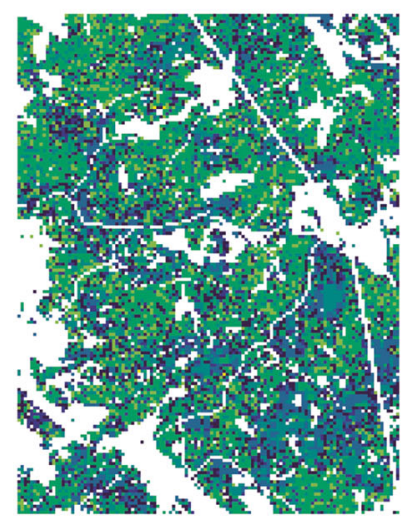

NEP in 2080

$(-0.3,-0.1]$

$(-0.1,0]$

$(0,0.1]$

$(0.1,0.2]$

$(0.2,0.4]$

$(0.4,0.5]$

$(0.5,0.6]$

NA

Fig. 3 A fine-scale visualisation of the simulated net ecosystem production (NEP) of forest for a subset of the study area in scenario 1 (no extraction of harvest residues for bioenergy production). The results represent the potential annual carbon uptake of forest before subtracting harvest removals. Positive values indicate that the ecosystem is a sink of carbon and negative values that it is a source 

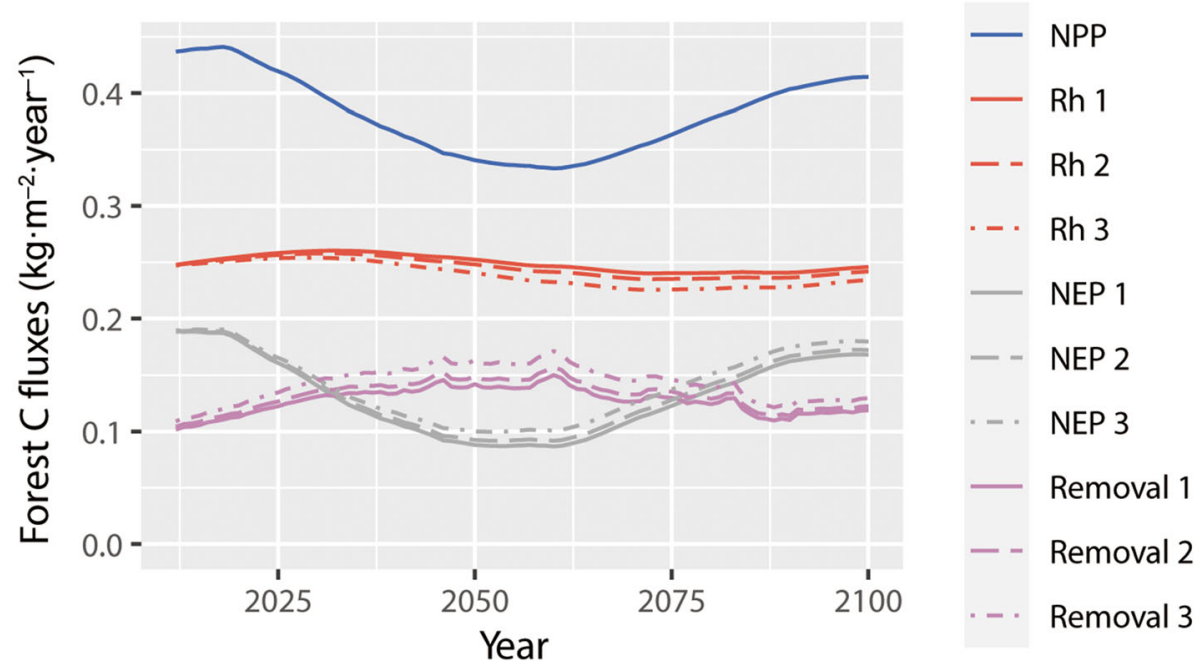

Fig. 4 The mean simulated carbon fluxes in the Vanajavesi catchment area over the simulation period 2012-2100 with bioenergy scenarios 1-3. NPP stands for net primary production, $R_{h}$ for heterotrophic respiration, NEP for net ecosystem production and harvest for the timber and energy-wood removal. The bioenergy scenarios 1-3 represent varying level of harvest residue removal: 1) no extraction of harvest residues, 2) extraction of branches and tree tops for bioenergy production, 3) extraction of branches, tree tops and stump-root systems for bioenergy production

algorithm. As a result of continued harvesting, the proportion of fast growing, middle-age stands declined leading to reduced NPP and, consequently, reduced accumulation of the biomass and soil carbon stocks. The carbon uptake of forest recovered along with the increasing proportion of fast-growing intermediate-aged stands (Fig. S1). The simulated and measured age class distribution differed to some extent in the beginning of the simulation period because they were based on different methods (Fig. S2). The measurements showed a higher proportion of very young and old stands and a lower proportion of intermediate aged stands than the simulations.

\section{Wood production and coarse woody litter}

The provisioning ecosystem services were shown as annual sums for the studied landscape (Fig. 5). The simulated mean annual timber production from the thinning and final felling sites was 0.91 mill. $\mathrm{m}^{3} \cdot$ year $^{-1}$ in $2012-$ 2100, with a range of $0.73-1.1$ mill. $\mathrm{m}^{3} \cdot$ year $^{-1}$ (Fig. 5a). The simulated estimate of timber harvest in 2012 was quite similar to the measured mean (Table 2). Both timber and energy-wood production peaked in the late 2050s, as more stands reached maturity, and decreased thereafter (Fig. 5a, b). In scenarios 2 and 3, the annual energy-wood potential from the final felling sites varied between 0.018 and 0.052 mill. $\mathrm{m}^{3}$ and 0.052 and 0.15 mill. $\mathrm{m}^{3}$, respectively (Fig. $5 \mathrm{~b}$ ). In other words, the extraction of stumps multiplied the energy-wood potential nearly three-fold compared with the extraction of only branches and tree tops. The simulated estimates of energy-wood removal in 2012 were comparable with the reported mean (Table 2).

The annual production of coarse woody litter from the thinning and final felling sites remained at a stable level in the study area in 2012-2100 (Fig. 5c). It followed the development of the total harvest removal in the study area because harvest residues were extracted only from the fertile spruce sites (Fig. 5a). In scenarios 1 and 2, the annual mean of coarse woody litter production was 0.18 mill. $\mathrm{m}^{3}$, with a range of $0.16-0.20$ mill. $\mathrm{m}^{3}$. These two scenarios produced the same estimates because only tree tops and stumps were classified as coarse woody litter and the simulated amount of tree tops was negligible. The extraction of stumps in scenario 3 reduced the annual production of coarse woody litter on average by 4.6\% (Fig. 5c). The simulated estimates correspond to the mean annual input of $0.23-0.25 \mathrm{t} \mathrm{C} \cdot \mathrm{ha}^{-1} \cdot$ year $^{-1}$ depending on the scenario.

\section{Discussion}

\section{Effects of bioenergy production on ecosystem services}

A refined framework to simulate ecosystem services related to carbon cycle was applied across a boreal forested landscape. Regular harvesting was the primary driver of the spatiotemporal variation of the ecosystem service estimates because it affected the forest age class distribution. The forests in the studied landscape acted first as a sink of carbon. However, they started to release carbon to the atmosphere when the harvest removals exceeded growth. The net carbon balance turned 


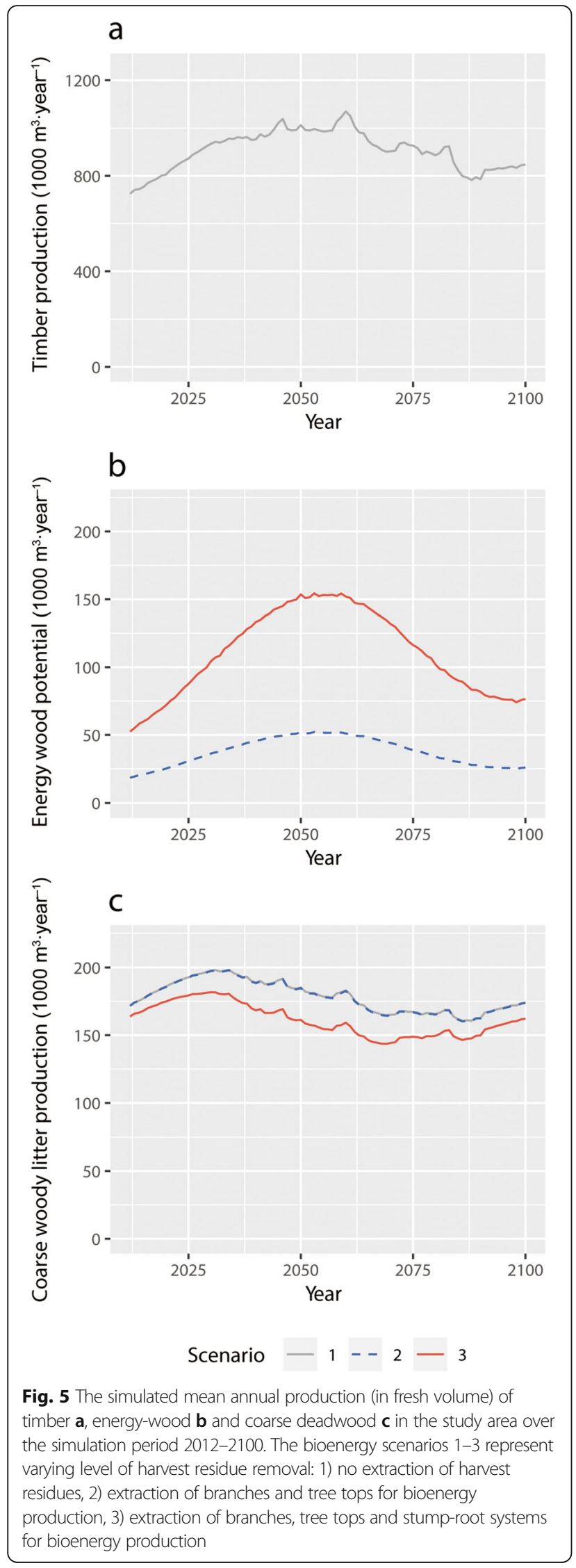

negative despite the positive values of NEP. The carbon sink recovered along with the increasing proportion of fast-growing intermediate-aged stands towards the end of the simulation period. A similar effect of forest age on productivity has also been observed in previous measurement (Pregitzer and Euskirchen 2004) and modelling experiments (Kohlmaier et al. 1995; Ťupek et al. 2010), supporting the findings of this study. It is noteworthy that at a national scale, Finnish forests act as a sink of carbon (Statistics Finland 2018). However, intensive harvests may turn a region to a temporary source of carbon (Pussinen et al. 2009), like shown in this study.

Based on the simulations, harvest residue extraction caused trade-offs between climate regulation, energywood production and habitat provisioning for deadwood dependent species. Extracting forest harvest residues in the final felling caused carbon loss from litter and soil compared with stem-only harvest. The level of harvest residue extraction increased towards the middle of the simulation period as more stands reached maturity. It declined again to the original level when the stand age class distribution approached the initial status. The annual coarse woody litter input to soil declined as a result of stump extraction in scenario 3, suggesting that continuing energy-wood harvesting reduces coarse deadwood formation in the long term, supporting the finding of Repo et al. (2020). Aboveground residue extraction in scenario 2 had a small impact on the simulated coarse woody litter production because the proportion of tree tops was so small.

Both fine and coarse deadwood are important for wood-inhabiting fungi (Juutilainen et al. 2014) and beetles (Jonsell et al. 2007), stressing the importance of retaining both fractions in the forest. In addition, about a quarter of all forest species in Fennoscandia is dependent on the availability of deadwood (Siitonen 2001). According to field experiments, the removal of harvest residues accelerates the breakage and disappearance of coarse logs (Rabinowitsch-Jokinen and VanhaMajamaa 2010; Herrmann et al. 2015). Therefore, the actual impacts of harvest residue extraction on both carbon sequestration and biodiversity could be more severe than estimated in this study. The extraction of harvest residues and stumps, together with the mechanical breakage reduced the amount of coarse deadwood on average $1-3.7 \mathrm{~m}^{3} \cdot \mathrm{ha}^{-1}$ (Repo et al. 2020).

\section{Evaluation of the mapping framework}

The validity of the mapping framework was evaluated by comparing the simulated and measurement-based ecosystem service indicators in the beginning of the simulation period. Based on the results, the simulated estimates of the biomass and soil carbon stocks were 
generally higher than the measurement-based estimates. The simulated biomass carbon stock change was, however, close to a previous model-based estimate (Forsius et al. 2016). The results may reflect a deviation of the studied sample from the larger population of forests which the measurements were taken from. The simulations produced the annual change in the total biomass of trees and ground vegetation whereas the measurement-based estimate included only tree growth. Moreover, the simulated estimate of the litter and soil carbon stock included also coarse woody litter unlike the observations, partly explaining the difference.

The deviations between the simulated and measured estimates of carbon stocks probably reflect differences of the simulated and actual forest management. In the model simulations, natural disturbances were absent, thinning, final felling and energy-wood harvest were assumed to occur always on time and only mature stands were regenerated. As a result of these assumptions, the estimates of stand growth, litter production and biomass potential might have been overly optimistic as also discussed earlier by Akujärvi et al. (2016). The simulated soil carbon stock change was very similar to the measured mean. The simulated timber and energy-wood removal were also in the order of magnitude with the inventory-based estimates, supporting the validity of the modelling approach.

The simulated coarse woody litter production could not be directly compared with inventory-based estimates due to methodological issues. The litter and soil carbon model Yasso15 does not separate the deadwood, litter and soil organic carbon (SOC) pools (Tuomi et al. 2011b; Didion et al. 2016). Based on earlier tests of the model, it can estimate the changes in the carbon pool of deadwood reliably given that input estimates are available (Didion et al. 2014; Hernández et al. 2017; Ziche et al. 2019). The simulated mean annual coarse woody litter input of the current study, $0.23-0.25 \mathrm{t} \mathrm{C} \cdot \mathrm{ha}^{-1}$. year $^{-1}$, was in the same order of magnitude with other modelled estimates, $0.5 \mathrm{t} \mathrm{C} \cdot \mathrm{ha}^{-1} \cdot \mathrm{year}^{-1}$ from G4M and $0.08 \mathrm{t} \mathrm{C}^{-\mathrm{ha}^{-1}}$.year $^{-1}$ from EFISCEN, respectively (Repo et al. 2015). It is worth noting the definitions of coarse wood litter differ in different studies. The estimate of the coarse woody litter production does not compare directly to the actual coarse woody debris in the study area because the former is an input to deadwood pool and the latter is the pool. Nevertheless, the results demonstrate the impacts of residue extraction on the formation of coarse woody debris and therefore on the deadwood abundance in the long term. All in all, the simulated estimates of ecosystem services in the beginning of the simulation period were comparable with measurements, supporting the validity of the mapping framework.
The quality of the initial data on forest characteristics is also an important aspect of the performance of the mapping framework. A broad spatial coverage and comprehensive information on forest characteristics are the strengths of the MS-NFI data compared with coarser land use and land cover maps (Kangas et al. 2018). However, MS-NFI is more accurate on medium and large spatial scales rather than on individual grid cells. This is because the $\mathrm{k}$ Nearest Neighbour method averages stand volumes and site fertility classes levelling off extremes (Katila 2006; Haakana 2017). Furthermore, errors in the MS-NFI data are spatially autocorrelated (Katila and Tomppo 2001). Considering these limitations, the mapping framework is more suitable for assessing ecosystem services at landscape level rather than on individual forest management units.

The simulated stand age structure was a key determinant of the landscape level projections of ecosystem services in this study. The differences between the simulated and measured age class distribution reflected mainly the deviation of the MS-NFI data from the field plot measurements. The age class distribution was initially biased by overestimating the proportion of intermediate-aged stands because of the limitations of the k Nearest Neighbours method (Katila 2006; Haakana 2017). In the later simulation years, the forest management scenarios started to dominate over the initial status. In the current study, regular harvesting reduced the amount of fast-growing intermediate-aged stands risking carbon sequestration temporarily. The climate impacts of forest management depend, however, also on the life cycle of the wood products which was outside the scope of this study. In the future, the approach could be developed by setting a limit of harvest removal that could not be exceeded. Another option would be to implement knowledge of the actual harvest ages to the landscape simulation. The mapping framework could also be refined with multiple model runs to cover the potential variation in harvest regimes.

\section{Implications for ecosystem service assessments}

The mapping framework presented in this study contributes to bridging the gap between mapping and simulation modelling in the ecosystem service assessments of boreal forests. It incorporated new features in comparison with some existing tools for ecosystem service assessment (Nelson et al. 2009; Maes et al. 2012). Firstly, the couplings of biomass, litter and soil carbon cycles were accounted for by the modelling approach, like in many process-based models (Morales et al. 2005). As a result, the dynamics of forest carbon cycle were described more accurately than in tools utilizing simple, land cover -based proxies (Eigenbrod et al. 2010). Secondly, the simple structure of the mapping framework is 
an advantage compared with some detailed, computationally intensive forest simulators (e.g. Redsven et al. 2004; Schelhaas et al. 2007; Rasinmäki et al. 2009;) or process-based models (e.g. Bayer et al. 2015; Gutsch et al. 2018; Holmberg et al. 2019). The modular structure of the mapping framework enables its flexible development with new data and models in the future. Thirdly, the presented framework featured a stochastic development of forest age structure across the landscape, reflecting the variability of management regimes. This is a refinement in comparison with some decision-support systems applying fixed age classes (Frank et al. 2015). However, it is not possible to draw conclusions about the supremacy of the stochastic approach for age structure based on the current results.

In the future, indicators of water quality regulation (Wade et al. 2002; Huttunen et al. 2016) or functional diversity (Vihervaara et al. 2017) could be integrated to the framework to study their relationships with carbon cycle. Fine scale maps allow for investigating the spatial trade-offs and synergies between carbon sequestration, other ecosystem services and biodiversity. Fine scale layers of carbon stocks and fluxes could support sustainable land use planning when integrated into a spatial prioritisation system (e.g. Mikkonen and Moilanen 2013; Kukkala and Moilanen 2017). The large variety of forest types and management systems in the boreal zone sets a challenge for applying the mapping framework at broad spatial scales. For example, growth and yield models for old-growth and uneven-aged forests (Pukkala 2016), as well as litter and soil carbon models for organic soils (Ojanen et al. 2014), are few and require more development. It is also noteworthy that scenario-based applications alone are inadequate tools for finding optimal solutions for land use (Mönkkönen et al. 2014). It would require simultaneous analysis of the alternative management regimes with multi-objective optimization tools (Eyvindson et al. 2018).

\section{Conclusions}

The mapping framework developed in this study integrated simulation modelling and spatially explicit, extensive data on forest characteristics. The approach produced reasonable estimates of the effects of bioenergy production on ecosystem services related to carbon cycle. It was suitable for assessing ecosystem services at the landscape level. Trade-off situations were observed between carbon sinks, wood production and coarse woody litter production as a result of continued harvest residue extraction for bioenergy production. The results demonstrated that stand age class distribution was a key driver of the simulated ecosystem service indicators across the study area. The framework contributes to bridging the gap between ecosystem service mapping and detailed simulation modelling in boreal forests. It allows for visualizing carbon stocks and fluxes as fine resolution maps to study their relationship with other ecosystem services and biodiversity. Fine scale maps of the impacts of forest management on carbon cycle could support sustainable land use planning. Future development of the framework includes integrating more detailed models and a wider variety of ecosystem service and biodiversity indicators to it.

\section{Supplementary Information}

The online version contains supplementary material available at https://doi. org/10.1186/s40663-021-00283-2.

Additional file 1: Figure $\mathbf{S 1}$ The development of the forest age class distribution in the Vanajavesi catchment area over the simulation period 2012-2100. Figure S2 The simulated (a) and measured (b) mean age class distribution in the study area in the beginning of the simulation period. The simulated and measured estimates represent the Vanajavesi catchment in 2012-2016 and the surrounding Kanta-Häme region in 2009-2013 (Natural Resources Institute Finland 2020), respectively.

\section{Abbreviations}

GPP: Gross Primary Production; MS-NFI: Multi-Source National Forest Inventory; NEP: Net Ecosystem Production; NBP: Net Biome Production; NPP: Net Primary Production; $R_{h}$ : Heterotrophic Respiration; SOC: Soil Organic Carbon.

\section{Acknowledgements}

The authors wish to thank Prof. Miska Luoto (University of Helsinki), Dr. Mikko Savolahti and Dr. Niko Karvosenoja (Finnish Environment Institute), as well as the anonymous reviewers for their constructive comments on the manuscript.

\section{Authors' contributions}

$A A, A R$ and $J$ outlined the original idea and study design. AA conducted the stand level forest simulations and AMA developed the stochastic landscape simulation. AA was a major contributor in interpreting the results and writing the manuscript with the support of AR. All authors read and approved the final manuscript.

\section{Funding}

AA has been supported by Maj and Tor Nessling Foundation through the grant "Coupling carbon sequestration of forests and croplands with ecosystem service assessments"(decision No. 201700251), LIFE+ financial instrument of the European Union (LIFE12 ENV/FI/000409, MONIMET) and the Academy of Finland Strategic Research Council project (SRC 2017) 312559 IBC-CARBON). AR has been supported by the Academy of Finland through the grant "Trade-offs and synergies in land-based climate change mitigation and biodiversity conservation" (decision No. 322066). We declare that the funding bodies were not involved in the design of the study, collection, analysis or interpretation of data or writing the manuscript.

\section{Availability of data and materials}

The datasets used and/or analysed during the current study are available from the corresponding author on reasonable request.

Ethics approval and consent to participate

Not applicable.

Consent for publication

Not applicable.

Competing interests

The authors declare that they have no competing interests. 


\section{Author details}

'Finnish Environment Institute SYKE, Biodiversity Centre, Latokartanonkaari 11, Fl-00790 Helsinki, Finland. ${ }^{2}$ University of Helsinki, Department of Geosciences and Geography, P.O. Box 64, Fl-00014 Helsinki, Finland. ${ }^{3}$ Natural Resources Institute Finland (Luke), P.O. Box 2, Fl-00791 Helsinki, Finland. ${ }^{4}$ VTT Technical Research Centre of Finland LTD, P.O. Box 1000, Fl-02044 VTT Espoo, Finland. ${ }^{5}$ Finnish Meteorological Institute, Climate System Research Unit, P.O. Box 503, Fl-00101 Helsinki, Finland.

Received: 9 April 2020 Accepted: 12 January 2021

Published online: 24 January 2021

\section{References}

Akujärvi A, Lehtonen A, Liski J (2016) Ecosystem services of boreal forests carbon budget mapping at high resolution. J Environ Manag 181:498-514

Alakangas E, Hurskainen M, Raatikainen-Luntama J, Korhonen J (2016) Properties of indigenous fuels in Finland. VTT Technology 272. http://www.vtt.fi/inf/pdf/ technology/2016/T272.pdf. Accessed 01 April 2020

Bayer AD, Pugh TAM, Krause A, Arneth A (2015) Historical and future quantification of terrestrial carbon sequestration from a greenhouse-gasvalue perspective. Glob Environ Change-Hum Policy Dimens 32:153-164

Bouget C, Lassauce A, Jonsell M (2012) Effects of fuelwood harvesting on biodiversity - a review focused on the situation in Europe. Can J For Res 42(8):1421-1432

Burkhard B, Kroll F, Nedkov S, Muller F (2012) Mapping ecosystem service supply, demand and budgets. Ecol Indic 21:17-29

Cajander AK (1949) Forest types and their significance. Acta Forest Fenn 56:1-71

Cherubini F, Guest G, Stromman AH (2013) Bioenergy from forestry and changes in atmospheric $\mathrm{CO}_{2}$ : reconciling single stand and landscape level approaches. J Environ Manag 129:292-301

Crossman ND, Bryan BA, de Groot RS, Lin YP, Minang PA (2013) Land science contributions to ecosystem services. Curr Opin Environ Sustain 5(5):509-514

Diaz-Yanez O, Mola-Yudego B, Anttila P, Roser D, Asikainen A (2013) Forest chips for energy in Europe: current procurement methods and potentials. Renew Sust Energ Rev 21:562-571

Didion M, Blujdea V, Grassi G, Hernandez L, Jandl R, Kriiska K, Lehtonen A, SaintAndre $L$ (2016) Models for reporting forest litter and soil $C$ pools in national greenhouse gas inventories: methodological considerations and requirements. Carbon Manag 7(1-2):79-92

Didion M, Frey B, Rogiers N, Thürig E (2014) Validating tree litter decomposition in the Yasso07 carbon model. Ecol Model 291:58-68

Eigenbrod F, Armsworth PR, Anderson BJ, Heinemeyer A, Gillings S, Roy DB, Thomas CD, Gaston KJ (2010) The impact of proxy-based methods on mapping the distribution of ecosystem services. J Appl Ecol 47(2):377-385

Eräjää S, Halme P, Kotiaho J, Markkanen A, Toivanen T (2010) The volume and composition of dead wood on traditional and forest fuel harvested clearcuts. Silv Fenn 44(2):203-211

Eriksson E, Gillespie AR, Gustavsson L, Langvall O, Olsson M, Sathre R, Stendahl J (2007) Integrated carbon analysis of forest management practices and wood substitution. Can J For Res 37(3):671-681

Evans D (2012) Building the European Union's Natura 2000 network. Nat Conserv Bulg 1:11-26

Eyvindson K, Repo A, Mönkkönen M (2018) Mitigating forest biodiversity and ecosystem service losses in the era of bio-based economy. Forest Policy Econ 92:119-127

Finnish Meterological Institute (2020) Monthly weather observations 1963-2015 available from the Finnish Meteorolical Institute's open data service by license CC BY 4.0. https://en.lmatieteenlaitos.fi/download-observations\#!/. Accessed 01 April 2020

Forsius M, Akujärvi A, Mattsson T, Holmberg M, Punttila P, Posch M, Liski J, Repo A, Virkkala R, Vihervaara P (2016) Modelling impacts of forest bioenergy use on ecosystem sustainability: Lammi LTER region, southern Finland. Ecol Indic 65:66-75

Frank S, Furst C, Pietzsch F (2015) Cross-sectoral resource management: how forest management alternatives affect the provision of biomass and other ecosystem services. Forests 6(3):533-560

Gao T, Nielsen AB, Hedblom M (2015) Reviewing the strength of evidence of biodiversity indicators for forest ecosystems in Europe. Ecol Indic 57:420-434

Gutsch M, Lasch-Born P, Kollas C, Suckow F, Reyer CPO (2018) Balancing tradeoffs between ecosystem services in Germany's forests under climate change. Environ Res Lett 13(4):12
Hernández L, Jandl R, Blujdea VNB, Lehtonen A, Kriiska K, Alberdi I, Adermann V, Canellas I, Marin G, Moreno-Fernandez D, Ostonen I, Varik M, Didion M (2017) Towards complete and harmonized assessment of soil carbon stocks and balance in forests: the ability of the Yasso07 model across a wide gradient of climatic and forest conditions in Europe. Sci Total Environ 599-600:1171-1180

Herrmann S, Kahl T, Bauhus J (2015) Decomposition dynamics of coarse woody debris of three important central European tree species. Forest Ecosyst 2:14. https://doi.org/10.1186/s40663-015-0052-5

Holmberg M, Aalto T, Akujärvi A, Arslan AN, Bergström I, Böttcher K, Lahtinen I, Mäkelä A, Markkanen T, Minunno F, Peltoniemi M, Rankinen K, Vihervaara P, Forsius M (2019) Ecosystem services related to carbon cycling - modeling present and future impacts in boreal forests. Front Plant Sci 10:343

Huttunen I, Huttunen M, Piirainen V, Korppoo M, Lepistö A, Räike A, Tattari S, Vehviläinen B (2016) A national-scale nutrient loading model for Finnish watersheds-VEMALA. Environ Model Assess 21(1):83-109

Hynynen J, Ojansuu R, Hökkä H, Siipilehto J, Salminen H, Haapala P (2002) Models for predicting stand development in MELA system. The Finnish Forest research institute. Res Papers. 835. http://www.metla.fi/julkaisut/mt/2002/835. htm. Accessed 01 April 2020

Hynynen J, Salminen H, Ahtikoski A, Huuskonen S, Ojansuu R, Siipilehto J, Lehtonen M, Rummukainen A, Kojola S, Eerikäinen K (2014) Scenario analysis for the biomass supply potential and the future development of Finnish forest resources. Metla Work Papers:302

Jonsell M, Hansson J, Wedmo L (2007) Diversity of saproxylic beetle species in logging residues in Sweden - comparisons between tree species and diameters. Biol Conserv 138(1-2):89-99

Juutilainen K, Mönkkönen M, Kotiranta H, Halme P (2014) The effects of forest management on wood-inhabiting fungi occupying dead wood of different diameter fractions. Forest Ecol Manag 313:283-291

Kangas A, Räty M, Korhonen K, Vauhkonen J, Packalen T (2019) Catering information needs from global to local scales-potential and challenges with national forest inventories. Forests 10(9):800

Karttunen K, Laitila J, Ranta T (2016) First-thinning harvesting alternatives for industrial or energy purposes based on regional scots pine stand simulations in Finland. Silv Fenn 50(2):1521

Katila M, Tomppo E (2001) Selecting estimation parameters for the Finnish multisource National Forest Inventory. Remote Sens Environ 76(1):16-32

Kilpeläinen A, Alam A, Strandman H, Kellomäki S (2011) Life cycle assessment tool for estimating net $\mathrm{CO}_{2}$ exchange of forest production. Glob Change Biol Bioenergy 3(6):461-471

Kohlmaier GH, Hager C, Wurth G, Lüdeke MKB, Ramge P, Badeck FW, Kindermann J, Lang T (1995) Effects of the age class distributions of the temperate and boreal forests on the global $\mathrm{CO}_{2}$ source-sink function. Tellus Ser B Chem Phys Meteorol 47(1-2):212-231

Koistinen A, Luiro J-P, Vanhatalo K (2016) Metsänhoidon suositukset energiapuun korjuuseen, työopas (Best Practices for Energy-wood Harvest). Tapio Group, p 78 (ien Finnish)

Kukkala AS, Moilanen A (2017) Ecosystem services and connectivity in spatial conservation prioritization. Landsc Ecol 32(1):5-14

Lautenbach S, Kugel C, Lausch A, Seppelt R (2011) Analysis of historic changes in regional ecosystem service provisioning using land use data. Ecol Indic 11(2): 676-687

Lavorel S, Bayer A, Bondeau A, Lautenbach S, Ruiz-Frau A, Schulp N, Seppelt R, Verburg P, van Teeffelen A, Vannier C, Arneth A, Cramer W, Marba N (2017) Pathways to bridge the biophysical realism gap in ecosystem services mapping approaches. Ecol Indic 74:241-260

Li XH, Farooqi TJA, Jiang C, Liu SR, Sun OJ (2019) Spatiotemporal variations in productivity and water use efficiency across a temperate forest landscape of Northeast China. Forest Ecosyst 6:13. https://doi.org/10.1186/s40663-019-0179-x

Liski J, Lehtonen A, Palosuo T, Peltoniemi M, Eggers T, Muukkonen P, Mäkipää R (2006) Carbon accumulation in Finland's forests 1922-2004 - an estimate obtained by combination of forest inventory data with modelling of biomass, litter and soil. Ann Forest Sci 63(7):687-697

Maes J, Paracchini ML, Zulian G, Dunbar MB, Alkemade R (2012) Synergies and trade-offs between ecosystem service supply, biodiversity, and habitat conservation status in Europe. Biol Conserv 155:1-12

Mäkipää R, Heikkinen J (2003) Large-scale changes in abundance of terricolous bryophytes and macrolichens in Finland. J Veg Sci 14(4):497-508

Mäkipää R, Linkosalo T, Komarov A, Mäkelä A (2014) Mitigation of climate change with biomass harvesting in Norway spruce stands: are harvesting practices carbon neutral? Can J For Res 45(2):217-225 
Matala J, Hynynen J, Miina J, Ojansuu R, Peltola H, Sievänen R, Väisänen H, Kellomäki S (2003) Comparison of a physiological model and a statistical model for prediction of growth and yield in boreal forests. Ecol Model 161(1-2):95-116

Melin Y, Petersson H, Egnell G (2010) Assessing carbon balance trade-offs between bioenergy and carbon sequestration of stumps at varying time scales and harvest intensities. Forest Ecol Manag 260(4):536-542

Mikkonen N, Moilanen A (2013) Identification of top priority areas and management landscapes from a national Natura 2000 network. Environ Sci Pol 27:11-20

Mina M, Bugmann H, Cordonnier T, Irauschek F, Klopcic M, Pardos M, Cailleret M (2017) Future ecosystem services from European mountain forests under climate change. J Appl Ecol 54(2):389-401

Mönkkönen M, Juutinen A, Mazziotta A, Miettinen K, Podkopaev D, Reunanen P Salminen H, Tikkanen OP (2014) Spatially dynamic forest management to sustain biodiversity and economic returns. J Environ Manag 134:80-89

Mononen L, Vihervaara P, Repo T, Korhonen KT, Ihalainen A, Kumpula T (2017) Comparative study on biophysical ecosystem service mapping methods-a test case of carbon stocks in Finnish Forest Lapland. Ecol Indic 73:544-553

Morales P, Sykes MT, Prentice IC, Smith P, Smith B, Bugmann H, Zierl B, Friedlingstein P, Viovy N, Sabate S, Sanchez A, Pla E, Gracia CA, Sitch S, Arneth A, Ogee J (2005) Comparing and evaluating process-based ecosystem model predictions of carbon and water fluxes in major European forest biomes. Glob Chang Biol 11(12):2211-2233

Natural Resources Institute Finland (2020) Soil types, age class distribution, stem biomass, growing stock volume and annual increment of growing stock on forest land and on poorly productive forest land, and industrial roundwood removals by region. Natural Resources Institute's interface service on August 142020 with the licence CC BY 4.0

Nelson E, Mendoza G, Regetz J, Polasky S, Tallis H, Cameron DR, Chan KMA, Daily GC, Goldstein J, Kareiva PM, Lonsdorf E, Naidoo R, Ricketts TH, Shaw MR (2009) Modeling multiple ecosystem services, biodiversity conservation, commodity production, and tradeoffs at landscape scales. Front Ecol Environ 7(1):4-11

Ojanen P, Lehtonen A, Heikkinen J, Penttilä T, Minkkinen K (2014) Soil $\mathrm{CO}_{2}$ balance and its uncertainty in forestry-drained peatlands in Finland. Forest Ecol Manag 325:60-73

Ortiz CA, Liski J, Gärdenäs Al, Lehtonen A, Lundblad M, Stendahl J, Agren Gl, Karltun E (2013) Soil organic carbon stock changes in Swedish forest soils-a comparison of uncertainties and their sources through a national inventory and two simulation models. Ecol Model 251:221-231

Paulick S, Dislich C, Homeier J, Fischer R, Huth A (2017) The carbon fluxes in different successional stages: modelling the dynamics of tropical montane forests in South Ecuador. Forest Ecosyst 4:11. https://doi.org/10.1186/s40663017-0092-0

Pregitzer KS, Euskirchen ES (2004) Carbon cycling and storage in world forests: biome patterns related to forest age. Glob Chang Biol 10(12):2052-2077

Pukkala T (2016) Which type of forest management provides most ecosystem services? Forest Ecosyst 3:16. https://doi.org/10.1186/s40663-016-0068-5

Pussinen A, Nabuurs GJ, Wieggers HJJ et al (2009) Modelling long-term impacts of environmental change on mid- and high-latitude European forests and options for adaptive forest management. Forest Ecol Manag 258(8):1806-1813

Rabinowitsch-Jokinen R, Vanha-Majamaa I (2010) Immediate effects of logging, mounding and removal of logging residues and stumps on coarse woody debris in managed boreal Norway spruce stands. Silv Fenn 44(1):51-62

Rasinmäki J, Mäkinen A, Kalliovirta J (2009) SIMO: an adaptable simulation framework for multiscale forest resource data. Comput Electron Agric 66(1): $76-84$

Redsven V, Anola-Pukkila A, Haara A, Hirvelä H, Härkönen K, Kettunen L, Kiiskinen A, Kärkkäinen L, Lempinen R, Muinonen E, Nuutinen T, Salminen O, Siitonen M (2004) MELA2002 reference manual (2nd edition). The Finnish Forest Research Institute, p 606

Repo A, Böttcher H, Kindermann G, Liski J (2015) Sustainability of forest bioenergy in Europe: land-use-related carbon dioxide emissions of forest harvest residues. GCB Bioenergy 7(4):877-887

Repo A, Eyvindson K, Halme P, Mönkkönen M (2020) Forest bioenergy harvesting changes carbon balance and risks biodiversity in boreal forest landscapes. Can J For Res doi:https://doi.org/10.1139/cjfr-2019-0284. Accessed 01 April 2020

Repo A, Järvenpää M, Kollin J, Rasinmäki J, Liski J (2016) Yasso15 graphical userinterface manual. http://en.ilmatieteenlaitos.fi/yasso. Accessed 01 April 2020
Repo A, Känkänen R, Tuovinen J-P, Antikainen R, Tuomi M, Vanhala P, Liski J (2012) Forest bioenergy climate impact can be improved by allocating forest residue removal. GCB Bioenergy 4(2):202-212

Repo A, Tuomi M, Liski J (2011) Indirect carbon dioxide emissions from producing bioenergy from forest harvest residues. Glob Change Biol Bioenergy 3(2):107-115

Routa J, Kellomäki S, Peltola H (2012) Impacts of intensive management and landscape structure on timber and energy wood production and net $\mathrm{CO}_{2}$ emissions from energy wood use of Norway spruce. Bioenergy Res 5(1):106-123

Sacchelli S, De Meo I, Paletto A (2013) Bioenergy production and forest multifunctionality: a trade-off analysis using multiscale GIS model in a case study in Italy. Appl Energy 104:10-20

Salminen H, Lehtonen M, Hynynen J (2005) Reusing legacy FORTRAN in the MOTTI growth and yield simulator. Comput Electron Agric 49(1):103-113

Scarlat N, Dallemand JF, Monforti-Ferrario F, Banja M, Motola V (2015) Renewable energy policy framework and bioenergy contribution in the European Union - an overview from National Renewable Energy Action Plans and Progress reports. Renew Sust Energ Rev 51:969-985

Schelhaas M-J, Eggers J, Lindner M, Nabuurs GJ, Pussinen A, Paivinen R, Schuck A Verkerk PJ, van der Werf DC, Zudin S (2007) Model documentation for the European Forest information scenario model (EFISCEN 3.1.3). Alterra report 1559 and EFI technical report 26. Alterra and European Forest Institute, Wageningen and Joensuu, p 118

Schlamadinger B, Spitzer J, Kohlmaier GH, Ludeke M (1995) Carbon balance of bioenergy from logging residues. Biomass Bioenergy 8(4):221-234

Schröter D, Cramer W, Leemans R, Prentice IC, Araujo MB, Arnell NW, Bondeau A, Bugmann H, Carter TR, Gracia CA, de la Vega-Leinert AC, Erhard M, Ewert F, Glendining M, House Jl, Kankaanpaa S, Klein RJT, Lavorel S, Lindner M, Metzger MJ, Meyer J, Mitchell TD, Reginster I, Rounsevell M, Sabate S, Sitch S, Smith B, Smith J, Smith P, Sykes MT, Thonicke K, Thuiller W, Tuck G, Zaehle S, Zierl B (2005) Ecosystem service supply and vulnerability to global change in Europe. Science 310(5752):1333-1337

Schulze E-D, Körner C, Law BE, Haberl H, Luyssaert S (2012) Large-scale bioenergy from additional harvest of forest biomass is neither sustainable nor greenhouse gas neutral. GCB Bioenergy 4(6):611-616

Sievänen R, Salminen O, Lehtonen A, Ojanen P, Liski J, Ruosteenoja K, Tuomi M (2014) Carbon stock changes of forest land in Finland under different levels of wood use and climate change. Ann Forest Sci 71(2):255-265

Siitonen J (2001) Forest management, coarse woody debris and saproxylic organisms: Fennoscandian boreal forests as an example. Ecol Bull 49:11-41

Sitch S, Smith B, Prentice IC, Arneth A, Bondeau A, Cramer W, Kaplan JO, Levis S, Lucht W, Sykes MT, Thonicke K, Venevsky S (2003) Evaluation of ecosystem dynamics, plant geography and terrestrial carbon cycling in the LPJ dynamic global vegetation model. Glob Chang Biol 9(2):161-185

Smith JE, Heath LS, Skog KE, Birdsey RA (2006) Methods for calculation Forest ecosystem and harvested carbon with standard estimates for Forest types of the United States. General technical report NE-343. Newtown Square, PA, USDA, Forest Service, northeastern Research Station. https://www.nrs.fs.fed. us/pubs/gtr/ne_gtr343.pdf. Accessed 01 April 2020

Statistics Finland (2018) Greenhouse gas emissions in Finland 1990-2016. National Inventory Report under the UNFCCC and the Kyoto Protocol. 15 April 2018. Statistics Finland. https://www.stat.fi/static/media/uploads/tup/ khkinv/fi_nir_un_2016_20180415.pdf. Accessed 19 Feb 2019

Sved J, Koistinen A (2015) Metsänhoidon suositukset kannattavaan metsätalouteen, työopas (best practices for profitable Forest management). Tapio Group, Helsinki (in Finnish)

Tomppo E, Haakana M, Katila M, Peräsaari J (2008a) Multi-source national forest inventory - methods and applications. Springer, Netherlands

Tomppo E, Katila M, Mäkisara K, Peräsaari J (2014) The multi-source National Forest Inventory of Finland - methods and results 2011. Working papers of the Finnish Forest research institute 319, Finland

Tomppo E, Olsson H, Stahl G, Nilsson M, Hagner O, Katila M (2008b) Combining national forest inventory field plots and remote sensing data for forest databases. Remote Sens Environ 112(5):1982-1999

Tuomi M, Laiho R, Repo A, Liski J (2011a) Wood decomposition model for boreal forests. Ecol Model 222(3):709-718

Tuomi M, Rasinmäki J, Repo A, Vanhala P, Liski J (2011b) Soil carbon model Yasso07 graphical user interface. Environ Model Softw 26(11):1358-1362

Tuomi M, Thum T, Järvinen H, Fronzek S, Berg B, Harmon M, Trofymow JA, Sevanto S, Liski J (2009) Leaf litter decomposition-estimates of global variability based on Yasso07 model. Ecol Model 220(23):3362-3371 
Tupek B, Zanchi G, Verkerk PJ, Churkina G, Viovy N, Hughes JK, Lindner M (2010) A comparison of alternative modelling approaches to evaluate the European forest carbon fluxes. Forest Ecol Manag 260(3):241-251

Vauhkonen J (2018) Predicting the provisioning potential of forest ecosystem services using airborne laser scanning data and forest resource maps. Forest Ecosyst 5:24. https://doi.org/10.1186/s40663-018-0143-1

Vauhkonen J, Ruotsalainen R (2017) Assessing the provisioning potential of ecosystem services in a Scandinavian boreal forest: suitability and tradeoff analyses on grid-based wall-to-wall forest inventory data. Forest Ecol Manag 389:272-284

Verkerk PJ, Fitzgerald JB, Datta P, Dees M, Hengeveld GM, Lindner M, Zudin S (2019) Spatial distribution of the potential forest biomass availability in Europe. Forest Ecosyst 6:11. https://doi.org/10.1186/s40663-019-0163-5

Vihervaara P, Auvinen A-P, Mononen L, Törmä M, Ahlroth P, Anttila S, Böttcher K, Forsius M, Heino J, Heliölä J, Koskelainen M, Kuussaari M, Meissner K, Ojala O, Tuominen S, Viitasalo M, Virkkala R (2017) How essential biodiversity variables and remote sensing can help national biodiversity monitoring. Global Ecol Conserv 10:43-59

Virkkala R (2016) Long-term decline of southern boreal forest birds: consequence of habitat alteration or climate change? Biodiversity and Conservation 25 (1): 151-167

Wade AJ, Durand P, Beaujouan V, Wessel WW, Raat KJ, Whitehead PC, Butterfield D, Rankinen K, Lepistö A (2002) A nitrogen model for European catchments: INCA, new model structure and equations. Hydrol Earth Syst Sci 6(3):559-582

Wihersaari M (2005) Greenhouse gas emissions from final harvest fuel chip production in Finland. Biomass Bioenergy 28(5):435-443

Zanchi G, Pena N, Bird N (2012) Is woody bioenergy carbon neutral? A comparative assessment of emissions from consumption of woody bioenergy and fossil fuel. GCB Bioenergy 4(6):761-772

Ziche D, Grüneberg E, Hilbrig L, Hohle J, Kompa T, Liski J, Repo A, Wellbrock N (2019) Comparing soil inventory with modelling: carbon balance in central European forest soils varies among forest types. Sci Total Environ 647:15731585

\section{Submit your manuscript to a SpringerOpen ${ }^{\circ}$ journal and benefit from:}

- Convenient online submission

- Rigorous peer review

- Open access: articles freely available online

High visibility within the field

- Retaining the copyright to your article

Submit your next manuscript at $\boldsymbol{\nabla}$ springeropen.com 